\title{
KVS ANNOUNCEMENTS
}

\section{TINBERGEN LECTURE}

The 2007 Tinbergen Lecture will be held on October 26, $15.30 \mathrm{hrs}$. Speaker will be Professor Raghuram Rajan (University of Chicago). Subject will be 'Financial Flows and Global Imbalances'.

\section{ANNUAL MEETING}

The Annual Meeting of the Royal Netherlands Economic Association will take place on Tuesday 11 December 2007, at Castle De Wittenburg in Wassenaar.

The topic of the Annual Meeting Papers 2007 is Private Equity. Editors are Sylvester Eijffinger (Tilburg University) and Kees Koedijk (Rotterdam School of Management).

For enquiries concerning the above meetings, please contact:

The Royal Netherlands Economic Association

Tel.: $+31-20-5242280$ c/o De Nederlandsche Bank

Fax: $+31-20-5242500$

P.O. Box 98

E-mail: kvs@dnb.nl

1000 AB Amsterdam

The Netherlands 